\author{
農林水産省野菜・茶業試験場* \\ 堀江秀 樹 \\ (平成11年 7 月 14 日受理)
}

\title{
Development of the Rapid Methods for the Analysis of Qualitatively Important Components in Tea Infusions
}

\author{
Hideki HORIE \\ National Research Institute of Vegetables, Ornamental Plants and Tea
}

\section{1.はじめに}

茶業における1990年代のトピックスの一つ に近赤外分光光度法の普及が上げられる。従 来, 専門家が独占していた化学分析法による と同様の成分分析值が，この方法を用いるこ とにより誰にでも簡単に得られるようになっ た。また一方で，カテキン類に代表される健 康維持機能を持つ化学成分名が一般大衆へと 普及したことと相まって, 茶の生産・流通関 係者の化学成分含量に対する関心は一層高ま りつつある。近赤外分光光度法は, 操作が簡 便で迅速な点では画期的ではある。しかしな がら，この方法の適用に当たっては検量線と 類似の試料に限られ，さらに浸出液の分析は 困難であり，近赤外法の適用範囲はきわめて 限定されたものである。さらに検量線の作 成・維持・管理には多大の労力を必要とする など, 必ずしも茶の品質関連成分分析の決定 的手法とはいえない。品質を評価する上では, 茶葉成分以外にも，実際に飲む状態での茶の 分析も重要なので, 茶の浸出液をも分析対象
とし，できるだけ簡易迅速にその品質に係わ る重要成分を分析できるよういくつかの手法 を開発したので紹介する。ここで取り上げる 手法は大きく2つに分けられ，一つは酵素を 用いた分析法であり，もう一つはキャピラ リー電気泳動法に基づくものである。

\section{2. 酵素を用いた茶成分の迅速分析}

\section{1 アミノ酸の分析 ${ }^{2-5)}$}

茶浸出液成分の中でも最も重要な成分は遊 離アミノ酸である。茶浸出液中の遊離アミノ 酸はアミノ酸分析計や高速液体クロマトグラ フィによっても分析できる゙が，この場合 1 試料の分析に 1 時間程度を要するので, その 簡易・迅速化が望まれてきた。そこで, 図 1 のような原理に基づく，バイオセンサーを導 入した2!このアミノ酸センサーでは, 酸素電 極の先端にL-アミノ酸オキシダーゼを固定 化した膜を装着している。L-アミノ酸オキシ ダーゼは，テアニン等のアミノ酸を酸化する 際に, 酸素を消費するので, 消費による酸素 濃度の低下を酸素電極で測定することによ

* $\quad \overline{\mathbf{T}} 428-8501$ 静岡県榛原郡金谷町金谷2769 


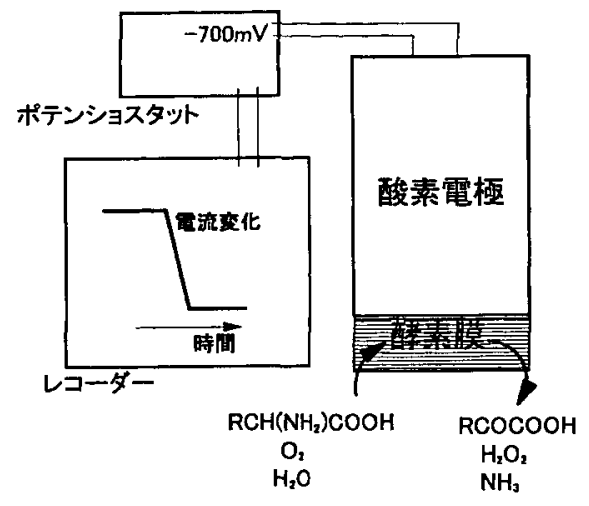

図 1 アミノ酸センサーの原理

酵素膜：L-アミノ酸オキシダーゼを膜に固定化 したもの。

り，アミノ酸の濃度を定量できる。

このような原理に基づくアミノ酸センサー とグルタミン酸センサーを組み合わせ，茶浸 出液中の全アミノ酸とグルタミン酸を同時に 迅速定量する手法を開発した（図 2) ${ }^{3}$ 。ここの 方法では, 分析の迅速化のためにフローイン ジェクション法を用い, 茶浸出液をろ過した

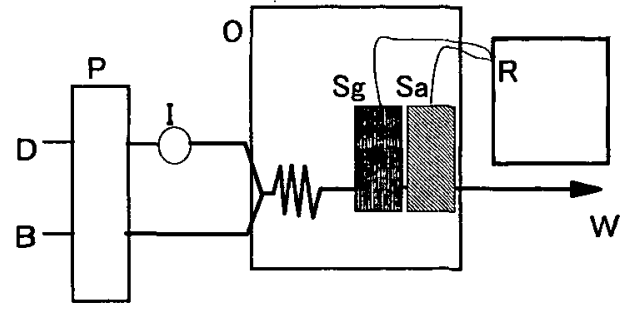

図 2 全アミノ酸・グルタミン酸同時分析用 フローインジェクション分析装置

$\mathrm{D}$ ：蒸留水 (流速 $0.7 \mathrm{ml} / \mathrm{min}), \mathrm{B}$ ：緩衝液 $(\mathrm{pH} 6.4$, $1 / 15 \mathrm{M}$ リン酸緩衝液, 流速 $2.7 \mathrm{ml} / \mathrm{min}), \mathrm{P}$ ：ペリスタ ポンプ, I : インジェクションバルブ $(100 \mu 1), \mathrm{Sg}$ : グルタミン酸センサー(グルタミン酸オキシダーゼ固 定化膜使用), $\mathrm{Sa}:$ アミノ酸センサー, $\mathrm{O}$ : 高速液体ク ロマトグラフィ用カラムオーブン $\left(30^{\circ} \mathrm{C}\right), \mathrm{R}:$ レコー ダー, W: 廃液。

試料を注射器から注入するだけで，2 分以内 に結果を得ることができた。同一条件で浸出 した場合，高価な茶ほど全アミノ酸の濃度が 高い傾向があり，また，グルタミン酸添加の 表示のある茶ではグルタミン酸の濃度が著し く高かった(図 3 )。本法は茶の品質詊価やグ ルタミン酸ナトリウム添加茶の判別への適用

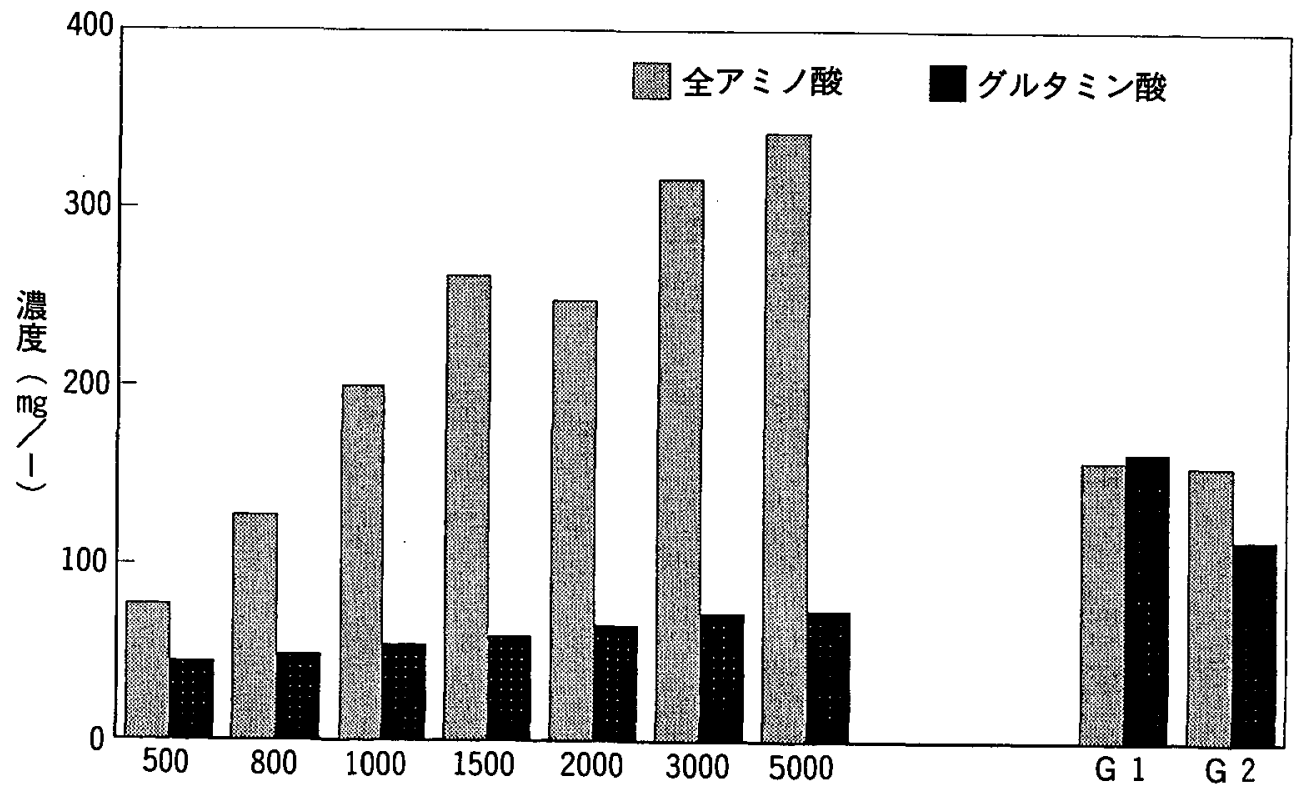

図 3 フローインジェクション法によって得られた茶浸出液中の全アミノ酸とグルタミン酸の濃度 数字は荒茶 $1 \mathrm{~kg}$ 当たりの単価を示す。G1及びG2は,グルタミン酸添加の表示のある市販茶。官能審查 液をろ過し，万液を図 2 の装置に注入した。 


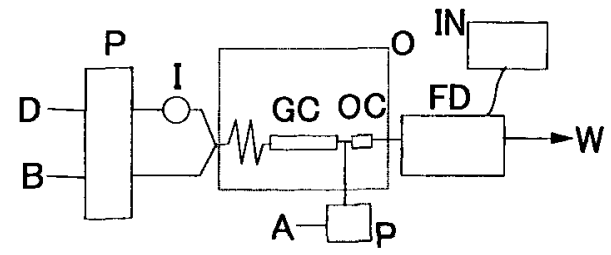

図 4 GABA分析用のフローインジェクション 装置

$\mathrm{D}$ ：蒸留水 (流速 $0.2 \mathrm{ml} / \mathrm{min}), \mathrm{B}:$ 緩衝液 $(\mathrm{pH} 8.0$, $100 \mathrm{mM}$ トリ又塩酸緩衝液, $400 \mathrm{mM}$ 硫酸ナトリウム, $1 \mathrm{mM} \mathrm{NADP}+, 5 \mathrm{mM}$ 2-ケトグルタル酸, $2 \mathrm{mM}$ メ ルカプトエタノールを含む。流速 $0.2 \mathrm{ml} / \mathrm{min}), \mathrm{P}:$ ポ ンプ, I : インジェクションバルブ $(20 \mu 1), \mathrm{GC}$ : GABAseを固定化したガラスビーズを詰めたりアク ター(内径 $1 \mathrm{~mm} \times$ 長さ $100 \mathrm{~mm}$ ), OC：ODS充填剂を 詰めた高速液体クロマトグラフフィ用ガードカラム, $\mathrm{O}$ ：高速液体クロマトグラフィ用カラムオーブン $\left(30^{\circ} \mathrm{C}\right), \mathrm{A}: 1 \%$ 酢酸水溶液 (流速 $\left.0.2 \mathrm{ml} / \mathrm{min}\right)$, $\mathrm{FD}$ : 蛍光検出器 (励起波長 $360 \mathrm{~nm}$, 検出波長 $460 \mathrm{~nm}$ ), IN : インテグレータ, W：廃永。

が期待される。

血圧上昇の抑制を目的に開発されたのが ギャバロン茶であり，その重要成分である $\gamma^{-}$ アミノ酪酸（GABA）についても簡便で迅速 な測定法についての要望が高い。GABAseは GABAアミノトランスフェラーゼとコハク 酸セミアルデヒドデヒドロゲナーゼの混合標 品として市販されている酵素で, 式 1 の反応 を触媒する。

$\mathrm{GABA}+2$-ケトグルタル酸 $+\mathrm{H}_{2} \mathrm{O}+\mathrm{NADP}^{+} \rightarrow$ コハク酸十グルタミン酸 $+\mathrm{NADPH}+\mathrm{H}^{+}($式 1$)$

そこでGABAseの作用により生成する補酵 素NADPHを蛍光検出する方法で, フロー分 析することを試みた ${ }^{4,5)}$ 。すなわち，GABAse はガラスビーズに固定化し，これをシリコン チューブに詰めてリアクターとし，その下流 に高速液体クロマトグラフィ用の蛍光検出器 を配置した(図 4)。さらに, 高速液体クロマ トグラフィ用充填剤をミニカラムに詰めて, 茶中の蛍光物質による妨害の除去を行った。 本法では 4 分毎にギャバロン茶の水抽出液を 注入し, ギャバロン茶中のGABAの定量を行 うことが可能であった。

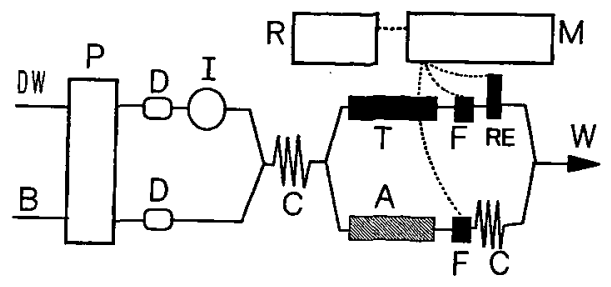

図 5 エステル型カテキン類分析用フローイン ジェクション装置

DW : 蒸留水， B ：緩衝液 $(500 \mathrm{mM}$ 塩化ナトリウムを 含む $10 \mathrm{mM}$ フタル酸緩衝液, pH5.5), P：ペリスタポ ンプ (総流速 $0.7 \mathrm{ml}) \mathrm{D} ：$ ダンパー, I : インジェク ションバルブ $(100 \mu 1), \mathrm{C}:$ :キシングコイル, T : タンナーゼを固定化したガラスビーズを詰めたリア クター (内径 $1 \mathrm{~mm} \times$ 長さ $20 \mathrm{~mm}$ ), A：対照リアク ター(牛血清アルブミンを固定化), $\mathrm{F}$ ：半導体 $\mathrm{pH}$ 電 極, $\mathrm{RE}:$ 比較電極: $\mathrm{M}: \mathrm{pH}$ メー夕本体, $\mathrm{R}:$ レコー ダー, W: 廃液。

\section{2 カテキン類の分析 ${ }^{6,7)}$}

茶のカテキン類は苦渋味を呈し, 重要な味 成分である。渋味を示すエステル型カテキン 類（エピガロカテキンガレート，エピカテキ ンガレート等）については, 酵素タンナーゼ の作用により，没食子酸を遊離する（式 2 ）。 エピガロカテキンガレート $+\mathrm{H}_{2} \mathrm{O} \rightarrow$ エピガロカテキン十没食子酸（式 2 )

そこで図 5 に示すような分析システムを組む ことにより，エステル型カテキン類の分析が 可能であった6)。すなわち，タンナーゼを固定 化したリアクターの下流に, 半導体のpH電極 を置き,没食子酸の生成に伴う $\mathrm{pH}$ の低下をモ ニタするわけである。このとき茶自身のpHに 由来する変化を差し引くため, アルブミンを 固定化したリアクターと別の $\mathrm{pH}$ 電極を並列 に設置し，2つの電極の電位差をモニタした。 この方法で 3 分毎に 1 試料の測定が可能と なった。

また，ゴボウには酵素ポリフェノールオキ シダーゼが含まれ，この酵素は酸素を消費し てカテキン類を酸化する。従ってゴボウの組 織片を酵素膜と同㥞に扱うことによっても， 
カテキン類の定量が可能と考えられる。寒際 にゴボウ切片と酸素電極を組み合わせること により, 茶出液中のカテキン類濃度の定量が 可能であった (図 6$)^{7)}$ 。

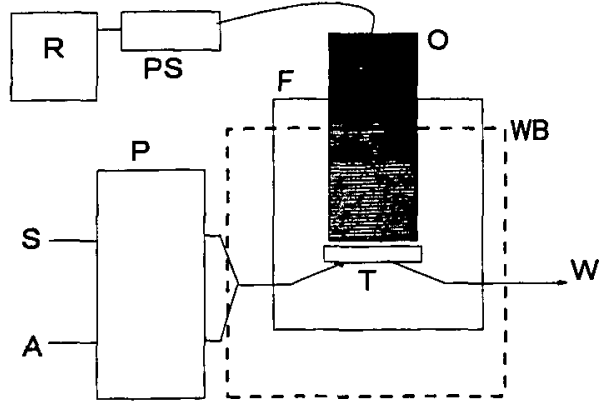

図 6 ゴボウ組織を用いたカテキン類の分析法 $\mathrm{S}: \mathrm{pH}$ 6.0，0.1M酥酸緩衝液 (ベースライン安定後, 同緩衝液で希釈した試料液と交換する。）A：空気, $\mathrm{P}$ : ポンプ (流速：各々 $2 \mathrm{ml} / \mathrm{min}), \mathrm{O}$ : 酸素電極, $\mathrm{T} ：$ ゴボウ組織(厚さ $0.2 \mathrm{~mm}), \mathrm{F}$ : フローセル, PS : ポテンショスタット, $\mathrm{R} ：$ レコーダー, $\mathrm{WB}$ ：恒温水 槽 $\left(25^{\circ} \mathrm{C}\right), \mathrm{W}$ : 廃液。

\section{$200 \mathrm{~nm}$}

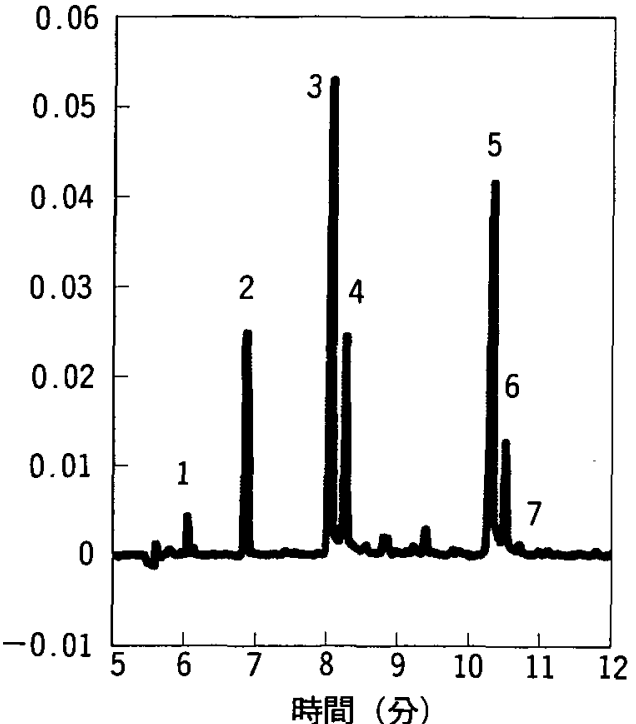

なおここで述べた方法での分析結果は， いずれの方法においても従来法による分析結 果と高い相関関係を得ている。

\section{3. キャピラリ一電気泳動法による茶成分の分析}

3.1 主要品質成分の同時分析 ${ }^{8 \sim 10}$

キャピラリー電気泳動法は内径 $0.1 \mathrm{~mm}$ 以 下という細管で電気泳動を行い，分離分析す る極めて新しい分析手法である。前章の酵素 を用いた手法では，酵素の基質特異性に依存 するため，迅速ではあるものの，複数成分の 同時分析を行うには系を複雑化しがちであ る。一方，キャピラリー電気泳動法では，分 離能が高いため,多成分の同時分析に適する。 そこで，この手法を茶の品質関連成分分析に 応用することを試み，茶葉抽出液および茶浸 出液中の主要カテキン類とカフェイン, テア ニン，アスコルビン酸を分離・定量すること に成功した(図 7)。ここでは，品質や価格と $270 \mathrm{~nm}$

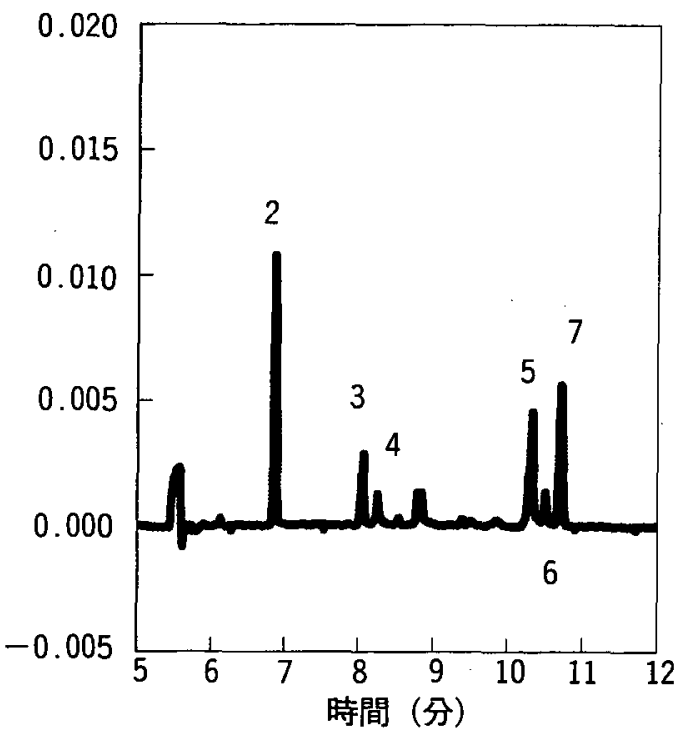

図 7 キャピラリー電気泳動法による茶主要成分の同時分析 (一番茶漫出液を0.1\%メタリン酸で希釈し, メンブレンフィルターを通した試料)

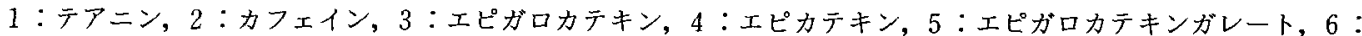

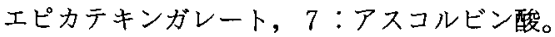

電気泳動液： $50 \mathrm{mM}$ ホウ酸, $10 \mathrm{mM}$ リン酸水素二ナトリウム, $50 \mathrm{mM} ト$ デシル硫酸ナトリム, $10 \%$ ○ノール $(\mathrm{pH} 8.2)$, 印加電圧： $25 \mathrm{kV}$ ，キャピラリ一温度 $20^{\circ} \mathrm{C}$, 試料注入： 5 秒間高压注入, キャピラリ一管：内径 $75 \mu \mathrm{m} \times$ 長さ $57 \mathrm{~cm}$, 検出：フォトダイオードアレイ検出器を利用し $200 \mathrm{~nm}$ と $270 \mathrm{~nm}$ の二波長で検出。 
の相関が高いことから分析需要の高い成分で あるテアニン ${ }^{11}$ は210nm以上の波長域では紫 外線の吸収を示さないため, 波長 $200 \mathrm{~nm}$ を選 択し，カテキン類とともにこの波長を検出に 用いた。一方，アスコルビン酸もまた緑茶鮮 度に関わる成分であり，可能なら同時分析が 望まれる。そこでフォトダイオードアレイ検 出器を用いて, 270nmを第 2 の検出波長とし て選択することにより，アスコルビン酸も含 めた同時分析を可能とした。最近カテキン類 とカフェインの高速液体クロマトグラフィ分 析に関する報告が多く発表されているが，そ の分析に要する時間は 1 試料につき 30 分以上 かかる場合が大部分である。ここに示した方 法では，キャピラリー管の洗浄を含めても 20 分以内に完了でき, しかも, カテキン類とカ フェイン以外にテアニンとアスコルビン酸の 分析も可能な点が特徴であり，近赤外分光法 の検量線作成を含め多方面での利用が期待で きる。
3.2 アニオン, カチオンの分析 ${ }^{12,15)}$

高速液体クロマトグラフィやイオンクロマ トグラフィを用いて，アニオンやカチオンの 分析を行う場合には，高価な専用カラムを準 備する必要がある。一方，ここで取り上げた キャピラリー電気泳動法においては，カテキ ン類などを分析したキャピラリー管をそのま ま利用できる点が利点である。

キャピラリー電気泳動法により，茶浸出液 中のシュウ酸, キナ酸, アスパラギン酸, グ ルタミン酸などが短時間に分離・分析できる 手法を開発した ${ }^{12)}$ (図 8)。本法により分析可 能な有機アニオン類の中でも，特にシュウ酸 に関しては, 従来茶の品質との関連では注目 されてこなかったが, 今後分析の必要性が高 くなるものと推察される。シュウ酸はホウレ ンソウなどで知られるエグ味物質であり，ま た著者らは，硬水で浸出した茶が白濁するの は，シュウ酸がカルシウム結合するためであ ると報告している ${ }^{13)}$ 。さらに,アルツハイマー

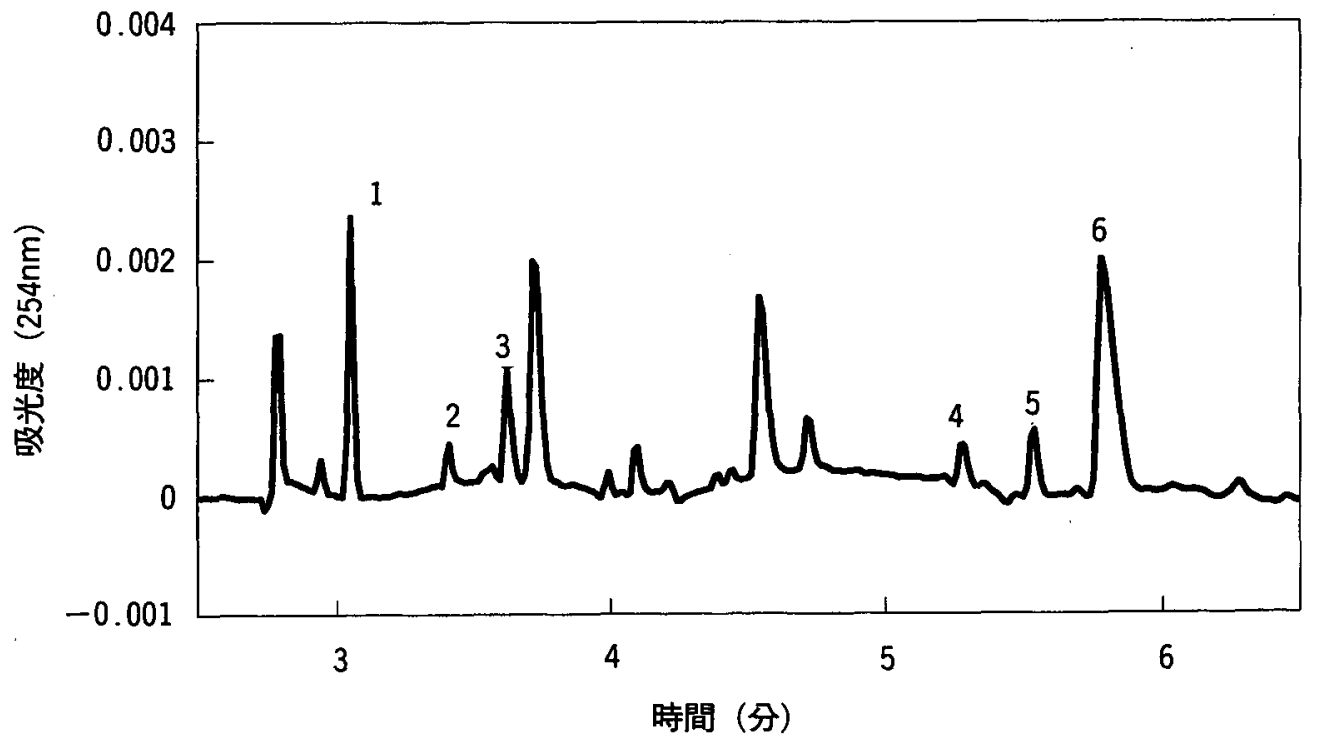

図 8 キャピラリ一電気泳動法による茶の有機アニオン分析（一番茶浸出液にエチレンジアミン四酢 酸二ナトリウムを $0.25 \mathrm{mM}$ 加え 5 倍希釈後メンフレンフィルターを通した試料）

1 : シュウ酸, 2 : クエン酸，3：リンゴ酸，4：アスパラギン酸，5：グルタミン酸，6：キナ酸。 電気泳動液： $10 \mathrm{mM}$ クムム酸ナトリウム, $0.5 \mathrm{mM}$ テラデシルトリメチルアンモニウムブロミド, $0.1 \mathrm{mM}$ エチレン ジアミン四酢酸二ナトリウム, 印加電圧： $-20 \mathrm{kV}$, キャピラリー温度 $20^{\circ} \mathrm{C}$, 試料注入： 5 秒間高圧注入, キャピラ リー管：内径 $75 \mu \mathrm{m} \times$ 長さ $57 \mathrm{~cm}$ ，検出 $254 \mathrm{~nm}$ (インダイレクト法)。 


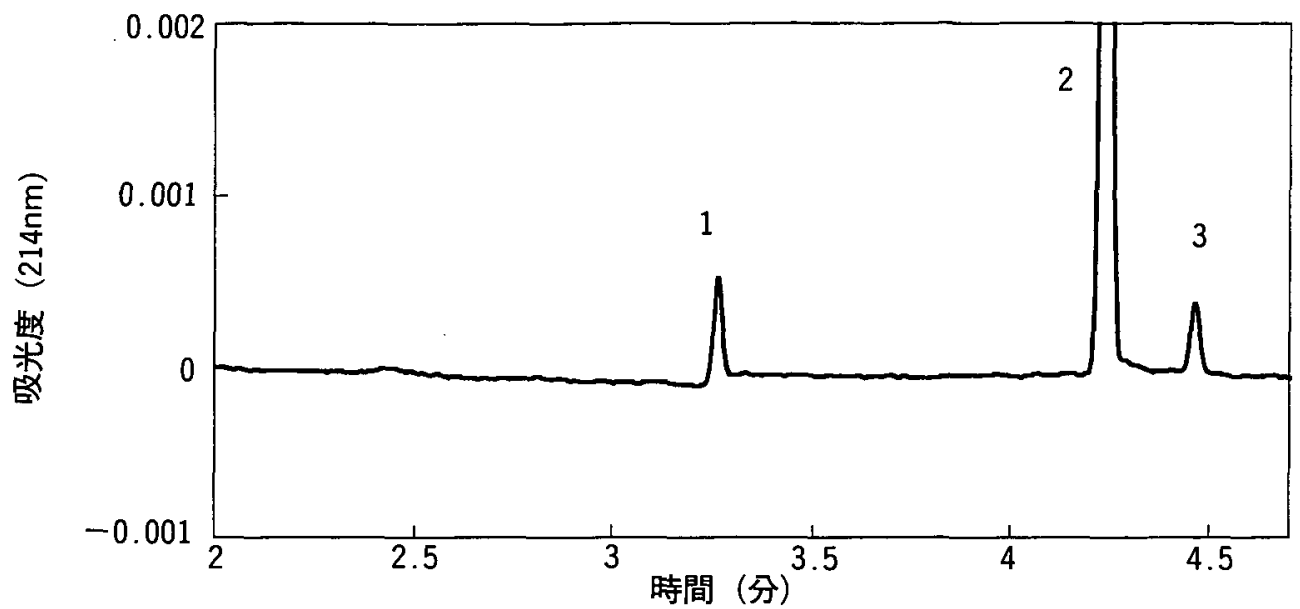

図 9 キャピラリ一電気泳動法による茶抽出液中のアンモニウムイオン, ナトリウムイオンの同時分析 （グルタミン酸ナトリウム添加の表示のある茶を $1 \mathrm{mM}$ 硝酸で抽出後，万液を10倍希釈希秎しメンフレンフィルターを通した詰料） $1:$ ナリウムイオン, 2 :アンモニウムイオン, $3:$ ア エルアミン。

電気泳動液：10mMイミダゾール, 20mM 18ークラウン 6 -エーテル (pH4.3), 印加電圧： $25 \mathrm{kV}$ ，キャピラリー温 度 $20^{\circ} \mathrm{C}$, 試料注入： 5 秒間高压注入, キャピラリー管：内径 $75 \mu \mathrm{m} \times$ 長さ $57 \mathrm{~cm}$, 検出: $214 \mathrm{~nm}$ (インダイレクト法)。

病などとの関連からアルミニウムの摂取が問 題とされるが, 著者らは, 茶浸出液中のアル ミニウムイオンの存在形態にもシュウ酸が影 響することも報告している ${ }^{14)}$ 。また一方で, 本 法によるアスパラギン酸及びグルタミン酸の 分析結果は, グルタミン酸ナトリウム添加茶 の判別のためにも, 利用できる可能性がある。

カチオンについては，アンモニウムイオン とナトリウムイオンの同時分析も可能であっ

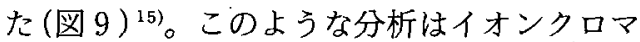
トグラフィにおいても可能ではあるが，高価 なカラムの寿命を延ばすためには，試料を十 分に希釈する必要があった。この操作は煩雑 であるばかりか，特にナトリウムイオンに関 してはコンタミネーションの危険が大きくな る。本法では，キャピラリー管が安価である ため希釈しなくとも污染を気にせずに分析す ることが可能で，キャピラリ一電気泳動装置 の普及に伴い，いわりる添加茶や発色茶の判 別 ${ }^{16,17)}$ に用いられることが期待される。

\section{4.おわりに}

新たに開発した茶成分の分析法について述 べた。これらの方法のうち酵素を用いた方法 に関しては，生産や流通の現場での利用も考
えて開発を進めたが，残念ながら現在のとこ ろ市販の装置をそのまま使用して分析を行う ことはできず, 装置の組立から自ら行う必要 がある。普及には，装置及び酵素膜や酵素り アクターの流通体制を整えることが必要であ る。一方, キャピラリー電気泳動法に関して は，市販の装置や試薬類がそのまま利用でき るものの，手法の普及には装置自身の普及を 待たねばならない。いずれにしても, 手法を 開発しただけでは片手落ちで, 開発した分析 法により分析が大幅に迅速化・省力化できる ようになった利点を十分に活かし，茶業に残 された多くの問題の解明に取り組むことが求 められる。

なお本研究は安田環元茶利用加工部長, 後 藤括久前品質化学研究室長の着想のもとに開 始されたものであり，研究推進に当たっては， 野菜・茶業試験場加らは国内・海外留学の機 会を与えていただいた。留学先では工業技衍 院水谷文夫 - 矢吹聡一両博士, 八ワイ大学 $\mathrm{G}$. A. Rechinitz教授に御指導を仰いだ。また, 本 研究の一部は静岡製機株式会社電子事業部と の共同研究の成果である。木幡勝則品質化学 研究室長を始め, 研究室で御助言いただいた 向井俊博技官（現野菜・茶業試験場花き部流 
通技術研究室長）ら研究推進にご協力いただ いた全ての方々に感謝したい。

\section{5. 引用文献}

1）後藤哲久 -堀江秀樹 - 向井俊博 (1993) : 緑茶中の主要アミノ酸のOPAによるプ レカラム誘導体化高速液体クロマトグラ フィーによる分析. 茶研報, No.77, 29-33.

2 ）堀江秀樹 - 向井俊博 - 後藤哲久 ・ 川中道 夫・下原 融（1992）：醉素センサーを用 いた茶浸出液中の全アミノ酸濃度の定 量. 茶研報, No.75, 33-37.

3 ）堀江秀樹 - 向井俊博 - 後藤哲久 ・権田実 敏・川中道夫（1993）：醉素センサーを用 いた茶浸出液中のアミノ酸のフローイン ジェクション分析。茶研報, No.78, 53-60.

4) HoRIE H. and G.A. Rechnitz(1995): Enzymatic flow injection determination of gamma-amino butylic acid. Analytical Letters, 28, 259-266.

5 ）堀江秀樹・澤井祐典・木幡勝則 (1999) : キャバロン茶中の $\gamma$-アミノ酷酸のフ ローインジェクション分析. 食科工, 46 , 494-496.

6) Horie H., T. Mukata, K. Kohata and T. GoTo (1997) : Flow injection analysis of (-)-epigallocatechin gallate in green tea infusions with an immobilized tannase reactor. Food Sci. Technol. Int. Tokyo, 3, 27-30.

7) Horie H., T. Mukai, T. Goto, M. KaWANAKA and T. SHIMOHARA(1994): Measurement of tea catechins uisng biosensors. 食工誌，41，433-435.

$8)$ Horie H., T. Mukai and K. Kohata (1997): Simultaneous determination of qualitatively important components in green tea infusions using capillary electrophoresis. J. Chromatogr. A, 758, 332-335.

9) HORIE H. and K. Kohata (1998):
Application of capillary electrophoresis to tea quality estimation. J. Chromatogr. A, 802, 219-223.

10）堀江秀樹 - 山崎祐作 ・ 山内雄二 ・ 木幡勝 則(1999)：キャピラリ一電気泳動法によ る茶の主要成分同時分析法の改良. 茶研 報, No.87, 59-65.

11）向井俊博・堀江秀樹 - 後藤哲久 (1992): 煎茶の遊離アミノ酸と全窒素の含量と価 格との関係について. 茶研報, No.76, 45-50.

12) HoRie H., Y. Yamauchi and K. Ko. HATA(1998): Analysis of organic anions in tea infusions using capillary electrophoresis. J. Chromatogr. A, 817, 139-144.

13）堀江秀樹・山内雄二・木幡勝則（1998）： 緑茶の硬水浸出液に生じる白色沈殿。食 科工, $45,364-367$.

14）堀江秀樹 - 向井俊博 - 後藤哲久 - 永田忠 博 (1994)： ${ }^{27} \mathrm{Al}-\mathrm{NMR}$ を用いた茶浸出液 中のアルミニウムの存在形態の解析. 食 工誌，41，120-122.

15）堀江秀樹・山内雄二・木憣勝則（1999）： キャピラリー電気泳動法による茶抽出液 中のナトリウムイオン及びアンモニウム イオンの同時分析. 茶研報, No.87. 81-84.

16）後藤哲久 - 堀江秀樹 - 向井俊博 - 谷口正 樹(1991)：イオンメーターによる茶葉中 のアンモニウムの簡易分析法. 茶研報, No.74, 11-13.

17）後藤哲久-堀江秀樹・向井俊博（1992）: 添加茶の化学成分による判別法。茶研報, No.75, 33-38. 